\title{
ROZWÓJ RYNKU LISTÓW ZASTAWNYCH W POLSCE W KONTEKŚCIE NOWYCH ZMIAN REGULACYJNYCH
}

\author{
Małgorzata Frańczuk \\ Katedra Finansów i Rachunkowości \\ Politechnika Lubelska
}

\begin{abstract}
Abstrakt. Listy zastawne są papierami wartościowymi, których celem emisji ma być refinansowanie kredytów hipotecznych udzielanych przez banki. W Polsce listy zastawne są wciąż mało popularne pomimo, że regulacje prawne w tym zakresie istnieją od 1997 roku. W artykule zwrócono uwagę na problem niewielkiego rozwoju listów zastawnych w Polsce oraz na szanse ich rozwoju w kontekście znowelizowanej ustawy o listach zastawnych i bankach hipotecznych oraz nowo wprowadzonych do polskiego porządku prawnego unijnej dyrektywy CRD IV oraz rozporządzenia CRR (tzw. pakietu CRD IV/CRR). W artykule opisano także sposób funkcjonowania listów zastawnych, banków hipotecznych i kredytu hipotecznego.
\end{abstract}

Słowa kluczowe: listy zastawne, banki hipoteczne, kredyty hipoteczne, płynność długoterminowa

\section{WSTĘP}

Rynek nieruchomości jest niezwykle istotny nie tylko w polskiej gospodarce, ale praktycznie w każdej gospodarce na świecie. W Polsce od wielu lat istnieje bardzo duże zainteresowanie tym rynkiem, m.in. ze względu na niezaspokojone potrzeby mieszkaniowe. Szacuje się, że w Polsce brakuje prawie 5 mln mieszkań [Kowalik 2016].

Z uwagi na konieczność poniesienia jednorazowych wysokich nakładów finansowych na zakup mieszkania, pojawia się problem jego finansowania. Jednym z najczęściej wykorzystywanych źródeł finansowania na rynku nieruchomości w Polsce jest kredyt hipoteczny udzielany przez banki na długie terminy. Środki na jego udzielenie banki pozyskują z krótkoterminowych depozytów. Powstaje $\mathrm{w}$ ten sposób problem z zachowaniem długoterminowej płynności w sektorze 
bankowym. Banki w Polsce już niedługo będą musiały poradzić sobie z tym tematem, gdyż od 1 stycznia 2018 roku zostaną zobowiązane do zachowania wskaźnika płynności długoterminowej w $100 \%$. Jest to związane z wprowadzeniem do polskiego porządku prawnego tzw. pakietu CRD IV/CRR w formie znowelizowanej ustawy o zmianie ustawy o nadzorze nad rynkiem finansowym oraz niektórych innych ustaw z dnia 5 sierpnia $2015 \mathrm{roku}^{1}$. Dyrektywa CRD IV oraz rozporządzenie CRR zostały opracowane w Parlamencie Europejskim w odpowiedzi na zaistniały kryzys finansowy zapoczątkowany w 2008 roku. Nowe regulacje prawne zakładają wiele zmian w sektorze bankowym m.in. konieczność zachowania przez banki wskaźnika płynności długoterminowej² ${ }^{2}$ Rozwiązaniem w tym zakresie mogą być listy zastawne, które emitowane na długie terminy, pozwalają pozyskać środki na refinansowanie kredytów hipotecznych.

W Polsce listy zastawne są emitowane, jednak biorąc pod uwagę liczbę emitentów i wartość emisji moża stwierdzić, że rynek ten jest nadal nierozwinięty m.in. przez niedopracowane regulacje prawne z 1997 roku dotyczące listów zastawnych. Dlatego też od 1 stycznia 2016 roku wprowadzono nowelizację ustawy z dnia 29 sierpnia 1997 roku o listach zastawnych i bankach hipotecznych.

\section{CEL I METODY BADAŃ}

Celem artykułu jest przedstawienie uwarunkowań rozwoju rynku listów zastawnych w Polsce w latach 1997-2016 oraz ich zmian w kontekście nowych regulacji prawnych dotyczących sektora bankowego (pakiet CRD IV/CRR) i listów zastawnych (ustawa o listach zastawnych i bankach hipotecznych).

Dla osiągnięcia zamierzonego celu $\mathrm{w}$ pracy zastosowano analizę regulacji prawnych dotyczących funkcjonowania listów zastawych i banków hipotecznych oraz pakiet CRD IV/CRR ze szczególnym uzwzględnieniem wskaźnika stabilnego finansowania (NSFR). Dokonano również analizy danych liczbowych ukazujących skalę finansowania przez sektor bankowy zakupu nieruchomości mieszkalnych, wysokości oprocentowania kredytów hipotecznych w Polsce oraz wartości emisji listów zastawnych w Polsce, a także w wybranych krajach Unii Europejskiej. Analiza danych liczbowych obejmuje lata 2011-2015. Ponadto przeprowadzono przegląd literatury przedmiotu, raportów, prasy oraz źródeł internetowych opisujących problematykę poruszaną w artykule.

\footnotetext{
${ }^{1}$ Ustawa z dnia 12 czerwca 2015 r. o zmianie ustawy o nadzorze nad rynkiem kapitałowym oraz niektórych innych ustaw. Dz.U. 2015 nr 0, poz. 12602015.11 .01

2 Komisja Nadzoru Finansowego, https://www.knf.gov.pl/crd/pakiet_crd4_zmiany_polskich_regulacji.html, [dostęp: 1.10.2016].
} 


\section{CHARAKTERYSTYKA LISTÓW ZASTAWNYCH I BANKÓW HIPOTECZNYCH}

Listy zastawne są papierami wartościowymi imiennymi lub na okaziciela, których emisja może być dokonana wyłącznie przez banki hipoteczne. Podstawę emisji i zabezpieczenie listów zastawnych stanowią wierzytelności banku z tytułu udzielonych kredytów hipotecznych ${ }^{3}$. Emisja listów zastawnych ma służyć refinansowaniu portfela kredytów hipotecznych, co w konsekwencji prowadzi do poprawy struktury bilansu banku.

Emitując listy zastawne bank hipoteczny zobowiązuje się wobec posiadacza tych instrumentów finansowych do spełnienia danych świadczeń pieniężnych w postaci wypłaty odsetek i ich wykupu w określonym terminie. Stąd listy zastawne można określić jako instrumenty o charakterze wierzycielskim (dłużnym) [Kaszubski i Olszak 2000]. Pojęciami stosowanymi w odniesieniu do listów zastawnych są: wartość nominalna, termin wykupu, oprocentowanie oraz terminy płacenia odsetek. Od wartości nominalnej naliczane są odsetki i jest ona zwracana inwestorowi w terminie wykupu listu zastawnego. Spłata zadłużenia wobec posiadacza listu zastawnego następuje w terminie wykupu. Oprocentowanie listu zastawnego określa wartość odsetek, która jest wypłacana z tytułu posiadania listu zastawnego w danych terminach. Odsetki płacone są inwestorom najczęściej raz w roku lub raz na pół roku. Oprocentowanie listu zastawnego może być stałe lub zmienne. W pierwszym przypadku jest ono niezmienne aż do terminu wykupu i znane już w momencie emisji. Przy zmiennym oprocentowaniu, wysokość odsetek wypłacanych w określonych terminach jest uzależniona od danej stopy referencyjnej np. WIBOR [Jajuga 2010].

Listy zastawne mogą być denominowane w złotych lub w walucie obcej. Mogą występować w postaci dokumentu lub w formie zdematerializowanej. Wyróżnia się dwa rodzaje listów zastawnych: hipoteczne i publiczne. Hipoteczny list zastawny jest papierem wartościowym, gdzie podstawą emisji są wierzytelności banku hipotecznego zabezpieczone hipotekami. Publiczny list zastawny jest papierem wartościowym, którego podstawę emisji stanowią wierzytelności banku hipotecznego z tytułu: kredytów zabezpieczonych gwarancją czy poręczeniem Skarbu Państwa, Narodowego Banku Polskiego, Europejskiego Banku Centralnego, rządów, banków centralnych państw członkowskich Unii Europejskiej, Organizacji Współpracy Gospodarczej i Rozwoju, jednostek samorządu terytorialnego lub kredytów udzielonych tym podmiotom ${ }^{4}$.

Listy zastawne uważa się za instrumenty bezpieczne min. dzięki tworzonym przez ustawodawcę regulacjom zabezpieczającym intersy nabywców tych papie-

\footnotetext{
${ }^{3}$ Ustawa z dnia 29 sierpnia 1997 r. o listach zastawnych i bankach hipotetycznych, Dz.U. 1997 nr 140, poz. 940, z poźn. zm., art. 3, ust. 1-2.

${ }^{4}$ Ibidem, art. 3, ust 1-2, art. 5.
} 
rów wartościowych. Kryzys finansowy zapoczątkowany w 2008 roku potwierdził wysoki poziom bezpieczeństwa listów zastawnych [Cyburt 2010].

Wyłączne prawo do emisji hipotecznych i publicznych listów zastawnych mają banki hipoteczne. Polska bankowość hipoteczna swoimi początkami sięga XVIII w., kiedy pojawiło się zapotrzebowanie na długoterminowy kredyty udzielane na nieruchomości, które były jednocześnie ich zabezpieczeniem [Heropolitańska i Michalski 2001]. Banki hipoteczne są instytucjami specjalistycznymi, które w swojej działalności skoncentrowane są na finansowaniu rynku nieruchomości. Emitując listy zastawne pozyskują one środki pieniężne na finansowanie działalności kredytowej. Kredyt hipoteczny definiowany jest jako rodzaj kredytu, gdzie zabezpieczenie stanowi hipoteka na nieruchomości. Zwykle z udziałem kredytu hipotecznego następuje finansowanie zakupu nieruchomości czy inwestycji budowlanej. Na rynku bankowym można spotkać się również z przypadkami refinansowania wydatków na wyżej wymienione cele czy zamiany nieruchomości [Liberadzki i Palimąka 2007]. Poza kredytami hipotecznymi bank hipoteczny może udzielać kredytów zabezpieczonych gwarancją czy poręczeniem Skarbu Państwa, Narodowego Banku Polskiego, Europejskiego Banku Centralnego, rządów, banków centralnych państw członkowskich Unii Europejskiej, Organizacji Współpracy Gospodarczej i Rozwoju, jednostek samorządu terytorialnego, mogą udzielać kredytów wyżej wymienionym podmiotom, mogą nabywać wierzytelności innych banków z tytułu kredytów hipotecznych oraz zabezpieczonych gwarancją czy poręczeniem wymienionych podmiotów. Poza tym banki hipoteczne mogą m.in. przyjmować lokaty terminowe, zaciągać kredyty i pożyczki, emitować obligacje, przechowywać papiery wartościowe, prowadzić rachunki bankowe do obsługi inwestycji realizowanych z kredytów udzielonych przez bank hipoteczny.

Bank hipoteczny prowadzi rejestr zabezpieczenia oddzielnie dla hipotecznych i publicznych listów zastawnych. Działalność banku hipotecznego podlega nadzorowi. Instutucją nadzorczą w tym zakresie jest Komisja Nadzoru Finansowego (KNF). W celu zwiększenia bezpieczeństwa funkcjonowania banku hipotecznego przy każdym z nich powoływany jest przez KNF powiernik i co najmniej jeden jego zastępca, którzy nie mogą być pracownikami banku. Liczba zastępców uzależniona jest od skali działalności banku hipotecznego ${ }^{5}$.

\section{ZMIANY W REGULACJACH PRAWNYCH DOTYCZĄCYCH LISTÓW ZASTAWNYCH I BANKÓW HIPOTECZNYCH W POLSCE}

Listy zastawne zostały wprowadzone do polskiego porządku prawnego ustawą z dnia 29 sierpnia 1997 roku o listach zastawnych i bankach hipotecznych, która weszła w życie w 1998 roku. Pierwsze listy zastawne wyemitowano w 2000 roku.

\footnotetext{
${ }^{5}$ Ibidem, art. 12 i 15 ust. 1 , art. 24 ust. 1, art. 27 ust. 1
} 
W porównaniu z większością krajów Unii Europejskiej polski rynek tych instrumentów można uznać za nierozwinięty. Na taki stan rzeczy wpłynęło kilka czynników, ale przede wszystkim niedopracowane przepisy prawne, które stworzyły bariery dla rozwoju tego rynku w Polsce. Można tu wymienić m.in. zbyt małą ustawową ochronę praw wierzycieli listów zastawnych, czy to, że banki uniwersalne, tak jak hipoteczne, mogły udzielać kredytów hipotecznych, jednak obowiązywały je mniejsze wymogi ostrożnościowe. Stąd propononowały one kredyty hipoteczne na korzytniejszych warunkach, niż mogły to robić banki hipoteczne. Wysokość kredytów udzielana przez banki uniwersalne sięgała nawet do 120\% wartości nieruchomości, podczas gdy banki hipoteczne mogły kredytować maksymalnie $70 \%$ wartości nieruchomości. Poza tym banki uniwersalne dysponowały tanim refinansowaniem kredytów pochodzącym od zagranicznych właścicieli, co spowodowało obniżenie marży na kredytach hipotecznych i wpłynęło na gwałtowny wzrost sprzedaży tych produktów oraz rozwój bankowości detalicznej [Raport z prac... 2013].

W związku ze znikomym funkcjonowaniem listów zastawnych w Polsce 31 sierpnia 2015 roku została podpisana nowelizacja ustawy z dnia 29 sierpnia 1997 roku o listach zastawnych i bankach hipotecznych, która weszła w życie 1 stycznia 2016 roku. Wprowadziła ona rozwiązania, które mają przyczynić się do rozwoju rynku listów zastawnych m.in. poprzez poprawę bezpieczeństwa funkcjonowania banków hipotecznych i samych posiadaczy listów zastawnych. Wśród wprowdzonych zmian jest m.in. określenie sposobu postępowania w sytuacji upadłości banku hipotecznego oraz w procesie zaspokajania jego wierzycieli. Trzeba nadmienić, iż roszczenia wierzycieli banku hipotecznego w sytuacji jego upadłości są zaspokajane w pierwszej kolejności i mają oni takie same prawa względem odrębnej masy upadłości. Kolejną zmianą w przepisach zwiększającą bezpieczeństwo nabywców listów zastawnych oraz samych banków hipotecznych jest konieczność utrzymywania zabezpieczenia listów zastawnych w wysokości co najmniej $110 \%$ wartości emisji, co oznacza, że zastosowano 10\% nadzabezpieczenie listów zastawnych. Wprowadzono także zabezpieczenie wypłaty odsetek od listów zastawnych znajdujących się w obrocie w okresie kolejnych 6 miesięcy. Ponadto bank hipoteczny nadal ma obowiązek prowadzić rejestr zabezpieczenia listów zastawnych, gdzie wpisywane są wierzytelności banku hipotecznego, ale zgodnie z nowelizacją ustawy do rejestru wpisywane są dodatkowo środki na pokrycie wypłaty odsetek. Nowością jest również konieczność przeprowadzania przez bank hipoteczny w każdym dniu roboczym rachunku zabezpieczenia listów zastawnych, aby sprawdzać czy wymogi w zakresie zabezpieczeń są wypełniane w długim okresie czasu. Ponadto według nowych przepisów bank hipoteczny przeprowadza tzw. test równowagi pokrycia polegający na określeniu czy wierzytelności wpisane do rejestru zabezpieczeń pokrywają w pełni nabywców listów 
zastawnych oraz test płynności polegający na ustaleniu czy te wierzytelności wystarczą na pokrycie zobowiązań wobec posiadaczy listów zastawnych w sytuacji upadłości banku hipotecznego, gdy terminy wymagalności jego zobowiązań są wydłużone do roku. Nowe przepisy wprowadzają również podwyższenie limitu refinansowania kredytów na nieruchomości mieszkalne ze środków pozyskanych w ramach emisji listów zastawnych z poziomu 60 do $80 \%$ bankowo-hipotecznej wartości nieruchomości ${ }^{6}$.

W warunkach poprzednich regulacji prawnych od 1999 roku funkcjonowały w Polsce dwa banki hipoteczne: Pekao Bank Hipoteczny S.A. z 70\% udziałem w rynku oraz mBank Hipoteczny S.A. (wcześniej BRE Bank Hipoteczny). Jednak już zapowiedź wprowadzenia nowych przepisów prawnych w zakresie funkcjonowania listów zastawnych i banków hipotecznych poskutkowała złożeniem przez kilka banków uniwersalnych wniosku do KNF o wydanie zezwolenia na utworzenie banków hipotecznych. Jako pierwszy z wnioskiem wystąpił Bank PKO BP S.A. i od 1 kwietnia 2015 roku rozpoczął swoją działalność PKO Bank Hipoteczny S.A. W marcu 2015 roku chęć utworzenia banku hipotecznego zadeklarował: Raiffeisen Polbank S.A., a w kwietniu 2015 roku. Getin Noble Bank S.A., składając stosowne wnioski do KNF. Według informacji podanych przez Getin Noble Bank S.A., jego bank hipoteczny rozpocznie działalność w 2017 roku?

Pierwsza emisja listów zastawnych zorganizowana przez PKO BH S.A. w grudniu 2015 roku poskutkowała sprzedażą listów zastawnych w wysokości $30 \mathrm{mln}$ zł. Druga emisja listów zastawnych przeprowadzona przez ten bank miała miejsce w kwietniu 2016 roku. Była to pierwsza w Polsce emisja listów zastawnych przeprowadzona według znowelizowanej ustawy o listach zastawnych i bankach hipotecznych oraz pierwsza w Polsce emisja zabezpieczona wyłącznie wysokiej jakości kredytami mieszkaniowymi. Przeprowadzona emisja o wartości $500 \mathrm{mln}$ zł pokazała, że istnieje duże zaintersowanie inwestorów listami zastawnymi. Budując księgę popytu bank ten uzyskał deklaracje nabycia listów zastawnych od inwestorów w kwocie 1,24 mld zł ${ }^{8}$.

\footnotetext{
${ }^{6}$ Ibidiem, art. 14, art. 18 ust. 1 i 3a, art. 24 ust. 1, art. 25 ust. 1 i 2, Dz.U. 2003 Nr 60 poz. 535 z późn. zm., art. 446 ust. 1.

${ }^{7}$ PKO Bank Hipoteczny S.A., http://www.pkobh.pl/o-banku/aktualnosci/nowy-gracz-narynku-kredytow-mieszkaniowych/, [data dostępu: 12.10.2016], Pekao Bank Hipoteczny S.A., http://www.pekaobh.pl/u235/navi/31467, [data dostępu: 12.10.2016], Raiffeisen Polbank S.A., http://raiffeisenpolbank.com/serwis-korporacyjny/aktualnosci/-/article/raiffeisen-polbank-zlozyl-wniosek-o-licencje-na-bank-hipoteczny, [data dostępu: 12.10.2016], http://www.bankier.pl/wiadomosc/Getin-Noble-Bank-chce-do-bankuhipotecznego-przeniesc-portfel-kredytow-o-wartosci-kilku-mld-zl-3322206.html

${ }^{8}$ PKO Bank Hipoteczny S.A., http://www.pkobh.pl/o-banku/aktualnosci/sukces-pierwszej-benchmarkowej-emisji-listow-zastawnych-pko-banku-hipotecznego, [data dostępu: 12.10.2016].
} 


\section{NOWE REGULACJE OSTROŻNOŚCIOWE W SEKTORZE BANKOWYM}

Kryzys finansowy zapoczątkowany w 2008 roku pokazał, że pomimo funkcjonujących w bankach standardów zarządzania ryzykiem wypracowanych przez Bazylejski Komitet ds. Nadzoru Bankowego (BCBS) w ramach tzw. Bazylei II, nie udało się zapobiec problemom, które pojawiły się w sektorze bankowym. W odpowiedzi na te wydarzenia BCBS pod koniec 2009 roku opublikował propozycje zmian $\mathrm{w}$ dotychczasowych regulacjach zawartych w nowej umowie kapitałowej, które w 2010 roku m.in. po zatwierdzeniu przez państwa należące do G20 stały się nowymi regulacjami w zakresie zarządzania ryzykiem w sektorze bankowym zwanymi Bazyleą III. W tym samym czasie Parlament Europejski pracował nad rozwiązaniami mającymi na celu wzmocnienie bezpieczeństwa systemu finansowego w państawach Unii Europejskiej w postaci tzw. pakietu CRD IV/CRR, w którym dokonano implementacji reguł Bazylei III. Obejmuje on znowelizowaną dyrektywę CRD oraz rozporząazenie CRR ${ }^{9}$. Wśród wprowadzonych zmian można wymienić m.in. bardziej restrykcyjne definicje elementów składowych funduszy własnych, dwa nowe rodzaje współczynników wypłacalności CET1 i Tier1 (oprócz dotychczasowego), koncepcje dwóch buforów kapitałowych: bufora ochrony kapitału i bufora antycyklicznego, ograniczenie współczynnika dźwigni, czy dwie nowe normy płynności mające na celu poprawę płynności w sektorze. Jednym z nowych wskaźników płynności jest wskaźnik pokrycia płynności (Liquidity Coverage Ratio - LCR) obrazujący płynność w ujęciu miesięcznym, a drugim wskaźnik stabilnego finansowania (Net Stable Funding Ratio - NSFR) ukazujący czy w banku istnieje stabilne, długoterminowe finansowanie (powyżej roku). Oblicza się go jako stosunek dostępnej wartości stabilnego finansowania do wartości wymaganej. W celu określenia dostępnej wartości finansowania stabilnego danym pozycjom po stronie pasywów przypisuje się określone wagi, co ma na celu ustalenie, które z nich będą dostępne po roku. Wyznaczając wymagany poziom finansowania stabilnego, podobnie jak w przypadku pasywów, aktywom i pozycjom pozabilansowym nadawane są wagi. Wyższą wagę otrzymują pozycje mniej płynne. Wskaźnik NSFR powinien kształtować się na poziomie powyżej 100\%. Wprowadzenie tego wskaźnika wymusza na bankach dokonanie zmian w procesie zarządzania płynnością finansową [Bazylea III... 2012].

To właśnie finansowanie $\mathrm{w}$ długim czasie i osiągnięcie wymaganego poziomu tego wskaźnika może stanowić problem dla banków w Polsce, które finansują długoterminowe kredyty za pomocą krótkoterminowych depozytów. Wynika to

${ }_{9}^{9}$ Komisja Nadzoru Finansowego, https://www.knf.gov.pl/crd/pakiet_crd4_historia.html, [data dostępu: 12.10.2016]. 
z faktu, że kredyty długoterminowe, $w$ tym hipoteczne są udzielane przez banki komercyjne, które nie mają możliwości emitowania długoterminowych papierów wartościowych tj. list zastawnych. Banki od 2015 roku musiały wykazać spełnienie wymogu płynności w 60\%, w 2016 roku w 70\%, w 2017 roku w 80\%, a już od 2018 roku nowe wskaźniki płynności będą musiały być na poziomie powyżej 100\% [Rozporządzenie Parlamentu Europejskiego... 2013].

\section{ANALIZA DANYCH LICZBOWYCH DOTYCZĄCYCH KREDYTÓW I LISTÓW ZASTAWNYCH}

Na podstawie danych zaprezentowanych w tabeli 1 wyraźnie widać, że następuje systematyczny wzrost sumy bilansowej w polskim sektorze bankowym w latach 2011-2015 do poziomu prawie 1,6 bln zł w 2015 roku. Widoczny jest również systematyczny wzrost akcji kredytowej banków, a wartość udzielonych kredytów w 2015 roku wyniosła ponad 1,1 bln zł.

TABELA 1. Wartość kredytów w aktywach banków w latach 2011-2015 (w mld zł)

\begin{tabular}{|l|r|r|r|r|r|}
\hline Wyszczególnienie & \multicolumn{1}{|c|}{2011} & 2012 & 2013 & \multicolumn{1}{c|}{2014} & \multicolumn{1}{c|}{2015} \\
\hline Kredyty & 936,5 & 957,9 & 995,8 & 1065,8 & 1135,3 \\
\hline Pozostałe pozycje bilansowe & 357,4 & 391,6 & 408,9 & 463,5 & 459,7 \\
\hline Suma bilansowa & 1293,9 & 1349,5 & 1404,7 & 1529,3 & 1595,0 \\
\hline
\end{tabular}

Źródło: Opracowanie własne na podstawie: Aktywa sektora bankowego, Narodowy Bank Polski, www.nbp.pl, [dostęp: 2.10.2016].

W strukturze aktywów sektora bankowego w latach 2011-2015 dominują kredyty. Można zauważyć ich stabilny udział w aktywach banków w granicach $70 \%$ (rysunek 1).

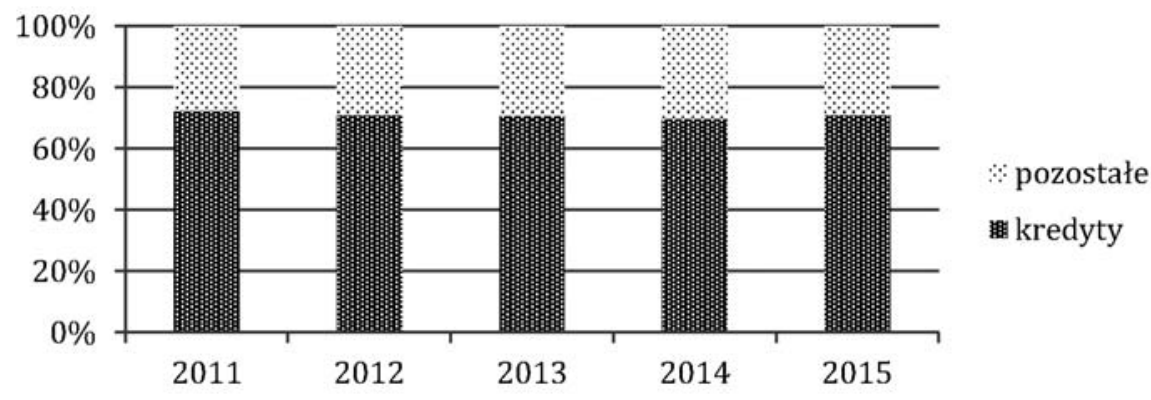

RYSUNEK 1. Struktura aktywów banków w latach 2011-2015

Źródło: Opracowanie własne na podstawie: Aktywa sektora bankowego, Narodowy Bank Polski, www.nbp.pl, [dostęp: 2.10.2016]. 
W ramach największej grupy spośród aktywów sektora bankowego, czyli kredytów dominują kredyty dla sektora niefinansowego, które w latach 2011-2015 powiększają swoją wartość. W 2015 roku osiągnęły one poziom 956,6 mld zł. Wśród kredytów dla sektora niefinansowego przeważają kredyty dla gospodarstw domowych, które również systematycznie rosną w badanych latach do poziomu blisko 625 mld zł (tabela 2).

TABELA 2. Wartość kredytów dla podmiotów sektora niefinansowego w latach 2011-2015 (w mld zł)

\begin{tabular}{|l|r|r|r|r|r|}
\hline Wyszczególnienie & 2011 & 2012 & 2013 & 2014 & 2015 \\
\hline Gospodarstwa domowe & 530,2 & 531,4 & 552,4 & 585,9 & 624,6 \\
\hline Przedsiębiorstwa & 264,3 & 272,1 & 278 & 300,9 & 326 \\
\hline Instytucje niekomercyjne & 4,2 & 4,9 & 5,2 & 5,6 & 6 \\
\hline Sektor niefinansowy & 798,7 & 808,4 & 835,6 & 892,4 & 956,6 \\
\hline
\end{tabular}

Źródło: Opracowanie własne na podstawie: Aktywa sektora bankowego, Narodowy Bank Polski, www.nbp.pl, [dostęp: 2.10.2016].

W latach 2011-2015 można zwrócić uwagę na przewagę finansowania gospodarstw domowych przez banki spośród wszystkich podmiotów sektora niefinansowego. Udział kredytów dla gospodarstw domowych w strukturze kredytów dla sektora sektora niefinansowego był stabilny we wszystkich badanych latach i wynosił około $66 \%$ (rysunek 2).

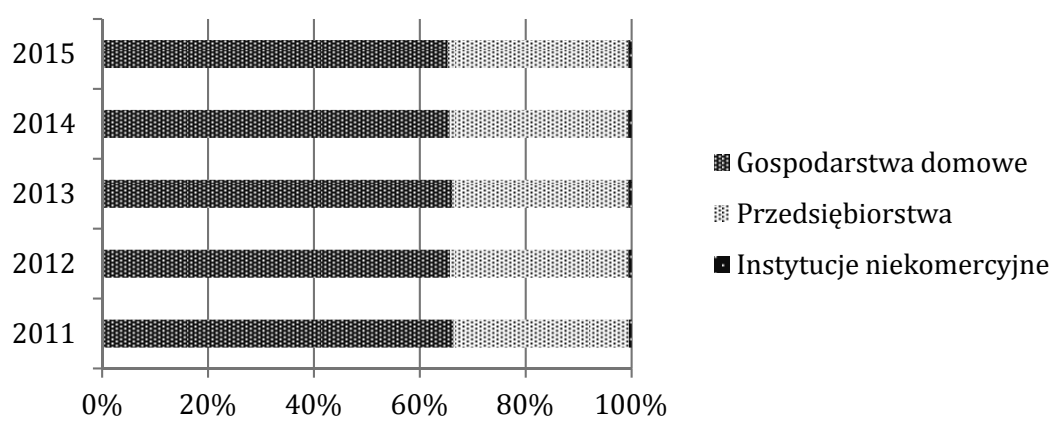

RYSUNEK 2. Struktura kredytów dla sektora sektora niefinansowego w latach 2011-2015

Źródło: Opracowanie własne na podstawie: Aktywa sektora bankowego, Narodowy Bank Polski, www.nbp.pl, [dostęp: 2.10.2016].

Analizując dane dotyczące kredytowania gospodarstw domowych przez banki można zauważyć, że najwięcej udzielają one kredytów mieszkaniowych. Ich udział w strukturze kredytów dla gospodarstw domowych w latach 2011-2015 
wynosił ponad 60\%. Widoczny jest również wzrost wartości długoterminowych kredytów mieszkaniowych w badanych latach, które w 2015 roku osiągnęły wartość ponad 378 mln zł (tabela 3, rysunek 3).

TABELA 3. Wartość kredytów dla gospodarstw domowych z uwzględnieniem kredytów mieszkaniowych w latach 2011-2015 (w mld zł)

\begin{tabular}{|l|r|r|r|r|r|}
\hline Wyszczególnienie & 2011 & 2012 & 2013 & 2014 & 2015 \\
\hline Kredyty mieszkaniowe & 317,7 & 320,3 & 333,9 & 353,5 & 378,1 \\
\hline Kredyty konsumpcyjne & 116,4 & 110,5 & 113,8 & 118,4 & 126,5 \\
\hline Pozostałe & 96,1 & 100,6 & 104,7 & 114,0 & 119,9 \\
\hline $\begin{array}{l}\text { Kredyty dla gospodarstw } \\
\text { domowych ogółem }\end{array}$ & 530,2 & 531,4 & 552,4 & 585,9 & 624,5 \\
\hline
\end{tabular}

Źródło: Opracowanie własne na podstawie: Aktywa sektora bankowego, Narodowy Bank Polski, www.nbp.pl, [dostęp: 2.10.2016].

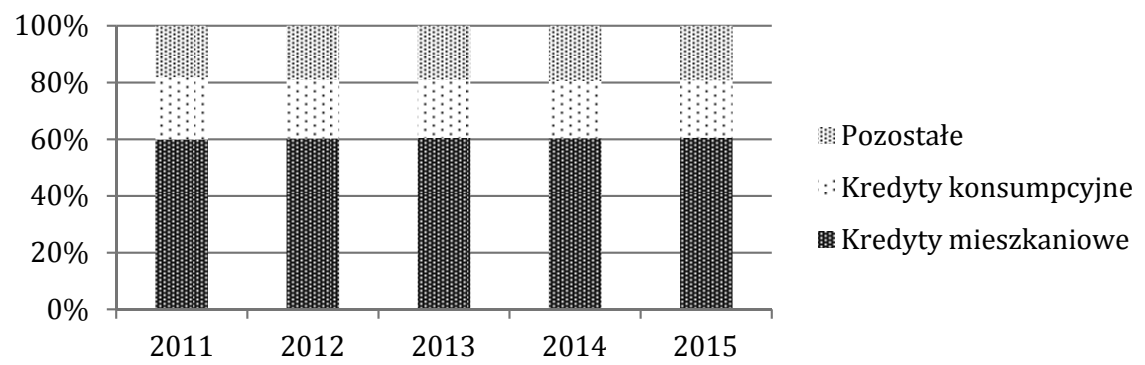

RYSUNEK 3. Struktura kredytów dla gospodarstw domowych w latach 2011-2015

Źródło: Opracowanie własne na podstawie: Aktywa sektora bankowego, Narodowy Bank Polski, www.nbp.pl, [dostęp: 2.10.2016].

Warto zwrócić uwagę na poziom średniego oprocentowania kredytów hipotecznych w badanych latach. Widoczny jest trend spadkowy (rysunek 4). Wynika on głównie z systematycznego obniżania stóp procentowych przez Radę Polityki Pieniężnej, co oznacza niższe raty kredytów denominowanych w złotych. Jednak z uwagi na to, że kredyty hipoteczne udzielane są na podstawie zmiennych stóp procentowych, to wzrost ich będzie oznaczał m.in. droższe kredyty hipoteczne. Jest to tzw. ryzyko stopy procentowej, które dzięki listom zastawnym może zostać ograniczone.

Listy zastawne są emitowane w Polsce od 2000 roku, jednak rynek ten nadal można uznać za mało rozwinięty, co potwierdzają dane zawarte w tabeli 4. Wartość polskich listów zastawnych zwiększała się z roku na rok przez ostatnich 5 lat osiągając wartość blisko 1,3 mld EUR w 2015 roku, co stanowiło ponad 31\% wzrost w stosunku do roku poprzedniego (tabela 5). 


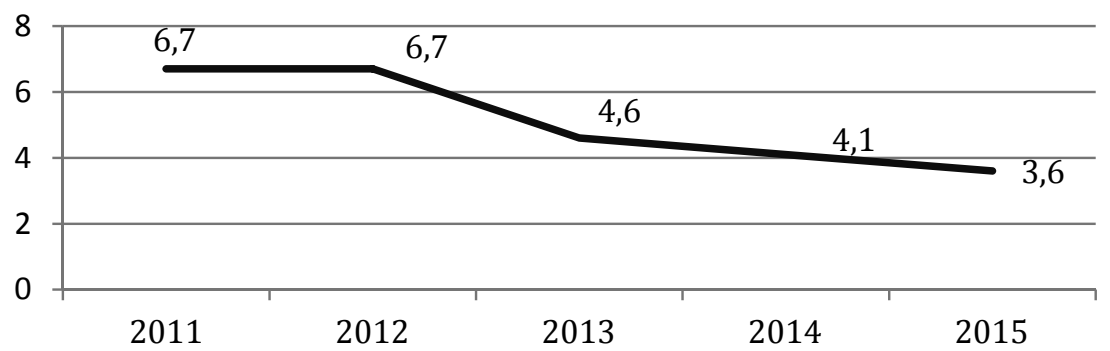

RYSUNEK 4. Średnie oprocentowanie kredytów hipotecznych w latach 2011-2015 (w \%) Źródło: Opracowanie własne na podstawie: Statystki stóp procentowych, Narodowy Bank Polski, www.nbp. pl, [dostęp: 2.10.2016].

TABELA 4. Wartość polskich listów zastawnych w latach 2011-2015 (w mln EUR)

\begin{tabular}{|l|r|r|r|r|r|}
\hline Wyszczególnienie & 2011 & 2012 & 2013 & 2014 & 2015 \\
\hline Hipoteczne listy zastawne & 527,1 & 657,1 & 706,5 & 882,0 & 1230,3 \\
\hline Publiczne listy zastawne & 112,2 & 110,4 & 84,0 & 81,9 & 35,2 \\
\hline Suma & 639,30 & 767,5 & 790,5 & 963,9 & 1265,5 \\
\hline
\end{tabular}

Źródło: Opracowanie własne na podstawie danych: The European Covered Bond Council (ECBC), www.ecbc.hypo.org, [dostęp: 8.10.2016].

TABELA 5. Dynamika wartości listów zastawnych w Polsce w latach 2012-2015 (w \%)

\begin{tabular}{|l|r|r|r|r|}
\hline \multirow{2}{*}{ Wyszczególnienie } & \multicolumn{4}{|c|}{ Rok poprzedni =100\% } \\
\cline { 2 - 5 } & 2012 & 2013 & 2014 & 2015 \\
\hline Hipoteczne listy zastawne & 124,7 & 107,5 & 124,8 & 139,5 \\
\hline Publiczne listy zastawne & 98,4 & 76,1 & 97,5 & 43,0 \\
\hline Suma & 120,1 & 103,0 & 121,9 & 131,3 \\
\hline
\end{tabular}

Źródło: Opracowanie własne na podstawie danych: The European Covered Bond Council (ECBC), www.ecbc.hypo.org, [dostęp: 8.10.2016].

W Polsce emitowane są przede wszystkim hipoteczne listy zastawne. Ich wartość w 2015 roku wyniosła ponad 1,2 mld EUR (tabela 4). Udział hipotecznych listów zastawnych w listach zastawnych ogółem w latach 2011-2015 był coraz większy, a w 2015 roku wyniósł aż ponad 97\% (tabela 6). Widoczny jest również wzrost wartości polskich hipotecznych listów zastawnych w badanych latach (rysunek 5). W 2015 roku ich wartość wzrosła o prawie 40\% w stosunku do roku poprzedniego (tabela 5). 
TABELA 6. Struktura polskich listów zastawnych w latach 2011-2015 (w \%)

\begin{tabular}{|l|r|r|r|r|r|}
\hline Wyszczególnienie & 2011 & 2012 & 2013 & 2014 & 2015 \\
\hline Hipoteczne listy zastawne & 82,4 & 85,6 & 89,4 & 91,5 & 97,2 \\
\hline Publiczne listy zastawne & 17,6 & 14,4 & 10,6 & 8,5 & 2,8 \\
\hline Suma & 100,0 & 100,0 & 100,0 & 100,0 & 100,0 \\
\hline
\end{tabular}

Źródło: Opracowanie własne na podstawie danych: The European Covered Bond Council (ECBC), www.ecbc. hypo.org, [dostęp: 8.10.2016].

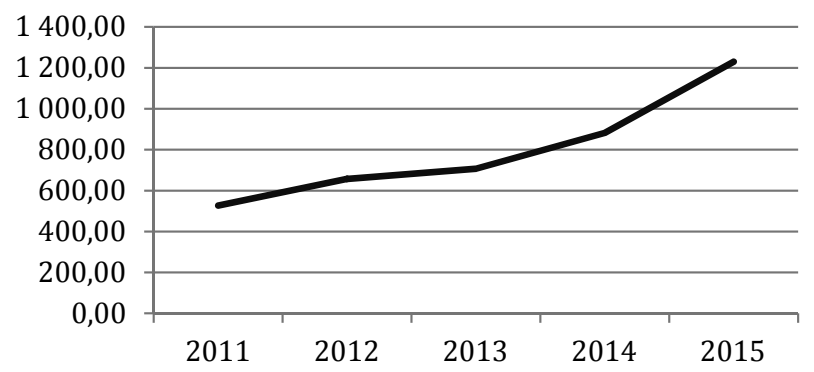

RYSUNEK 5. Wartość hipotecznych listów zastawnych w latach 2011-2015 (w mln EUR) Źródło: Opracowanie własne na podstawie danych: The European Covered Bond Council (ECBC), www.ecbc. hypo.org, [dostęp: 8.10.2016].

W celu określania poziomu rozwoju listów zastawnych w Polsce dokonano porównania ich wartości do listów zastawnych emitowanych w wybranych krajach Unii Europejskiej (tabela 7). W 2015 r. największy udział pod względem wartości listów zastawnych wykazywały Niemcy, w których wartość listów za-

TABELA 7. Wartość oraz struktura listów zastawnych w wybranych krajach Unii Europejskiej w 2015 roku

\begin{tabular}{|l|c|c|}
\hline \multicolumn{1}{|c|}{ Wyszczególnienie } & Wartość (w mln EUR) & Struktura (\%) \\
\hline Niemcy & 384414 & 18,26 \\
\hline Dania & 383124 & 18,20 \\
\hline Francja & 323072 & 15,34 \\
\hline Austria & 44965 & 2,14 \\
\hline Czechy & 11656 & 0,55 \\
\hline Słowacja & 4198 & 0,20 \\
\hline Węgry & 3022 & 0,14 \\
\hline Polska & 1266 & 0,06 \\
\hline Cypr & 650 & 0,03 \\
\hline Łotwa & - & - \\
\hline Suma wszystkich krajów UE & 2105421 & 100,00 \\
\hline
\end{tabular}

Źródło: Opracowanie własne na podstawie danych: The European Covered Bond Council (ECBC), www.ecbc. hypo.org, [dostęp: 8.10.2016]. 
stawnych to kwota ponad 384 mld EUR. Na drugim miejscu znalazła się Dania z wartością listów zastawnych ponad 383 mld EUR, a na trzecim Francja, gdzie ich wartość wyniosła ponad 323 mld EUR. Polski rynek listów zastawnych na tle wybranych krajów Unii Europejskiej jest jednym z najmniej rozwiniętych. Udział wartości polskich listów zastawnych w ogólnej ich wartości we wszystkich krajch Unii Europejskiej to 0,06\%. Niższą wartość listów zastawnych wykazywał jedynie Cypr, a Łotwa w ogóle nie emitowała lisów zastawnych.

\section{WNIOSKI}

Na podstawie zaprezentowanych zmian w regulacjach prawnych dotyczących listów zastawnych i banków hipotecznych oraz pakietu CRD IV/CRR, a także bazując na przedstawionych badaniach można sformułować następujące wnioski:

1. Obowiązująca od 1 stycznia 2016 roku znowelizowana ustawa o listach zastawnych i bankach hipotecznych wprowadza wiele rozwiązań, które zwiększają bezpieczeństwo banków hipotecznych i posiadaczy listów zastawnych. Wysoki poziom bezpieczeństwa może zwiększyć skłonność do inwestowania w te papiery wartościowe, których wartość w Polsce według zaprezentowanych danych liczbowych jest wciąż niska, w porównaniu z innymi krajami Unii Europejskiej.

2. Kredyty stanowią główną pozycję aktywów w sektorze bankowym, a wśród nich dominują te dla gospodarstw domowych, które zaciągają przede wszystkim kredyty mieszkaniowe. Obserwuje się również przyrost kredytów, w tym mieszkaniowych udzielanych przez banki w latach 2011-2015. Biorąc pod uwagę te zależności aktualny staje się problem poszukiwania przez banki źródeł długoterminowego finansowania aktywności kredytowej. Listy zastawne wydają się odpowiednim instrumentem $w$ tym zakresie.

3. Wprowadzenie unijnej dyrektywy CRD IV i rozporządzenia CRR do polskiego porządku prawnego, których jednym z najważniejszych elementów jest konieczność zapewnienia przez banki płynności długoterminowej, czyli utrzymywanie wskaźnika NSFR na poziomie powyżej 100\% już od 1 stycznia 2018 roku, powoduje konieczność zmiany polityki zarządzania płynnością finansową. Potwierdzeniem możliwych zmian w sektorze bankowym prowadzących do rozwoju rynku listów zastawnych jest utworzenie PKO Banku Hipotecznego S.A. w 2015 roku i prowadzenie przez niego skutecznych emisji listów zastawnych oraz złożenie wniosków do Komisji Nadzoru Finansowego o utworzenie banków hipotecznych przez Getin Noble Bank S.A. i Raiffeisen Polbank S.A. 
Podsumowując powyższe wnioski można stwierdzić, że listy zastawne jako instrumenty refinansowania kredytów hipoteczych mają realne szansę na rozwój w Polsce w najbliższych latach i mogą przyczynić się do poprawy bezpieczeństwa sektora bankowego.

\section{Spis literatury}

Aktywa sektora bankowego, Narodowy Bank Polski, www.nbp.pl, [dostęp: 2.10.2016].

Bazylea III - miary płynności i bufory kapitałowe 2012: Nowoczesny Bank Spółdzielczy,

$1,46,51-52$.

CYBURT P. 2010: Polski list zastawny - bilans po 10 latach, Finansowanie Nieruchomości, nr 07-09, s. 4-5.

HEROPOLITAŃSKA I., MICHALSKI M. 2001: Hipoteka, listy zastawne, obligacje hipoteczne, TWIGGER, Warszawa.

JAJUGA K. 2010: Instrumenty zabezpieczone hipotecznie, [w:] A. Szelągowska (red.), Współczesna bankowość hipoteczna, CeDeWu, Warszawa, s. 95.

KASZUBSKI R. W., OLSZAK M. 2000: Bank hipoteczny. Zagadnienia prawne, Difin, Warszawa.

LIBERADZKI M., PALIMĄKA A. 2007: Bankowość hipoteczna, [w:] M. Zaleska (red.), Współczesna bankowość, Difin, Warszawa, s. 203.

Rozporządzenie Parlamentu Europejskiego i rady (UE) nr 575/2013 z dnia 26 czerwca 2013 r. w sprawie wymogów ostrożnościowych dla instytucji kredytowych i firm inwestycyjnych, zmieniające rozporządzenie (UE) nr 648/2012, Dz.U. L 176/1 z 27.6.2013.

Raport z prac Grupy ds. emisji listów zastawnych przez banki 2013, Komisja Nadzoru Finansowego.

KOWALIK F. 2016: Narodowy Program Mieszkaniowy ma rozwiązać odwieczny polski problem. Czy się uda?, http://www.forbes.pl/narodowy-program-mieszkaniowy-marozwiazac-odwieczny-polski-problem-czy-sie-uda-,artykuly,206155,1,4.html, [dostęp: 13.09.2016].

Statystki stóp procentowych, Narodowy Bank Polski, www.nbp.pl, [dostęp: 2.10.2016]. The European Covered Bond Council (ECBC), www.ecbc.hypo.org, [dostęp: 8.10.2016].

\section{THE COVERED BONDS MARKET DEVELOPMENT PERSPECTIVES IN THE CONTEXT OF NEW REGULATIONS}

Abstract. Covered bonds are securities which purpose of the issue is to be the refinancing of mortgage loans granting by banks. In Poland, covered bonds are still undeveloped, although the legislation in this area has existed since 1997. The article draws attention to the problem of a small development of covered bonds in Poland and the chances of their development in 
the context of the amended Act on Covered Bonds and Mortgage Banks and the newly introduced into the Polish legal order of the EU directive CRD IV and CRR regulation (called CRD IV/CRR package). In the article it is also described the way of functioning of covered bonds, mortgage banks and mortgage loan.

Key words: covered bonds, mortgage banks, mortgage loans, long-term liquidity 